Article

\title{
Rural Population Decline, Cultivated Land Expansion, and the Role of Land Transfers in the Farming-Pastoral Ecotone: A Case Study of Taibus, China
}

Zhen Liu ${ }^{1,2}$

check for updates

Citation: Liu, Z. Rural Population Decline, Cultivated Land Expansion, and the Role of Land Transfers in the Farming-Pastoral Ecotone: A Case Study of Taibus, China. Land 2022, 11, 256. https://doi.org/10.3390/ land11020256

Academic Editor: Luca Salvati

Received: 7 January 2022

Accepted: 6 February 2022

Published: 8 February 2022

Publisher's Note: MDPI stays neutral with regard to jurisdictional claims in published maps and institutional affiliations.

Copyright: (C) 2022 by the author. Licensee MDPI, Basel, Switzerland. This article is an open access article distributed under the terms and conditions of the Creative Commons Attribution (CC BY) license (https:// creativecommons.org/licenses/by/ $4.0 /)$
1 Institute of Geographic Sciences and Nature Resources Research, Chinese Academy of Sciences, 11A Datun Road, Chaoyang District, Beijing 100101, China; liuz.15b@igsnrr.ac.cn

2 Key Laboratory of Regional Sustainable Development Modeling, Chinese Academy of Sciences, Beijing 100101, China

\begin{abstract}
The decline and aging of the rural population in China has been an increasingly conspicuous problem in the past few decades and has been one of the fundamental drivers of cultivated land abandonment and loss. However, although they have endured similar rural demographic changes, some regions have experienced cultivated land expansion and the farming-pastoral ecotone is a typical one. Using Taibus as a case, this study aims to reveal the phenomenon of cultivated land expansion in the context of rural population decline and explore its underlying mechanism by addressing the role of cultivated land protection and land transfer policies. This study will also reveal the possible negative impacts and risks of cultivated land expansion. We found that $64.3 \%$ of the rural population in Taibus have migrated to other regions in 2020; however, cultivated land has increased by more than $10 \%$ in the past five years. Land transfer policies have helped to solve the agricultural labor shortage problem and increase household income, which encouraged the reclamation activities by rural households. However, under China's land protection system, the central and the local governments have not enough incentives to prevent these reclamation activities. Cultivated land expansion in the farming-pastoral ecotone may lead to a series of negative impacts or risks, especially the overuse of groundwater resources and land desertification. Thus, we suggest that governments pay more attention to the phenomenon of cultivated land expansion and re-assess the cultivated land use policies in the farming-pastoral ecotone and other regions with similar contexts.
\end{abstract}

Keywords: rural population decline; cultivated land; land transfer; land abandonment; the farmingpastoral ecotone; China

\section{Introduction}

Cultivated land use is a common concern worldwide because it is closely associated with food security [1-7]. In many regions or countries, such as Europe, the United States, Australia, Latin America, and Southeast Asia, cultivated land abandonment has already been a major trend [6,8]. Farmland abandonment is driven by a variety of factors, including urbanization and rural population outmigration, land system reform, and declining agricultural profits [9]. Simultaneously, large-scale cultivated land expansion has also been observed in numerous regions, including those with limited water resources, which has been linked to population growth and agricultural development [10-12]. Cultivated land change has significantly altered rural land use patterns, the agricultural landscape, and ecological effects.

In China, rural population decline caused by massive rural population outmigration has profoundly impacted agriculture land use in rural areas [13,14]. Rural population decline has induced land abandonment, which is one of the reasons behind cultivated land loss [15-22]. The percentage of abandoned land area as a part of the total cultivated land area can range from $10-20 \%$ in many provincial units [18]. To address the problem 
of land abandonment, the Chinese central government issued the land transfer policy on agricultural land in 2014. This policy allows rural households to trade their land usage rights to others, if they are unwilling or unable to engage in agricultural production $[23,24]$. In 2017, more than $30 \%$ of all household farmers transferred their rural lands to another party with the total area of rural land transfer amounting to more than 33 million hectares ("ha" for short), which accounts for about 35\% of the total household land area [25,26]. Many studies have pointed out the positive impacts of land transfer, including the prevention of cultivated land abandonment, improving the income of rural households, and the promotion of large-scale agricultural management $[17,27-30]$.

While many productive farming areas have experienced cultivated land abandonment and losses, reclamation activities and cultivated land expansion are higher in some less productive western and border provinces [31,32]. One such region is the farming-pastoral ecotone. The farming-pastoral ecotone in northern China has a total cultivated area of about 26.9 million ha in 2010, and it has increased by over 0.5 million ha in the past decade [28], which deserves attention from scholars and policymakers. First, this phenomenon happened against the backdrop of a continuous nationwide loss of cultivated land, even though these regions have also experienced a rapid decline in rural population [29]. Second, many of these regions are ecologically fragile areas with scarce water resources. Cultivated land expansion will only consume more water resources, which may further aggravate the water shortage and cause environmental degradation [33,34]. Nonetheless, few studies have explored the mechanisms of cultivated land expansion in the farming-pastoral regions.

Cultivated land expansion may be affected by lots of factors, such as temperature and rainfall, socioeconomic factors, application of new agricultural technology, and the prices of agricultural products [33,35-38]. However, we believe that agricultural land use policies are what have fundamentally influenced cultivated land change [39]. First, agricultural support policies (subsidies, tax incentives, etc.) can directly encourage the expansion of cultivated land. Second, loose policy restrictions on reclamation activities can also encourage the expansion of cultivated land.

Cultivated land change in the farming-pastoral ecotone may be more strongly affected by rural land use policies [28,31]. The income of rural households is relatively low, and agricultural development still plays an important role in these regions. Moreover, rural households can choose to engage in land cultivation or animal husbandry, which are directly affected by the changes in land use policies. However, it is worth mentioning that most rural households are farmers instead of herdsmen, so they may tend to engage in cultivated land production if these two kinds of economic activities bring in a similar level of income. Thus, as an important new aspect of agricultural land use policy, the possible impact of land transfer policy on the changes in cultivated land in the farming-pastoral ecotone deserves more discussion.

Using Taibus (a typical farming-pastoral region in Inner Mongolia) as the case area, this study aims to reveal the phenomenon of cultivated land expansion in the context of rural population decline in the farming-pastoral ecotone in China. It also aims to explore the underlying mechanisms of this phenomenon from the perspective of policy analysis, which emphasizes the role of cultivated land protection and land transfer policies in the process of cultivated land expansion. This study contributes to our understanding of the various impacts of cultivated land use policies in different regional contexts and helps improve the cultivated land use policies in the farming-pastoral ecotone and other regions with similar contexts.

This study is organized as follows. Section 1 is the introduction; Section 2 introduces the background of Chinese cultivated land protection policies and the research framework; Section 3 provides an overview to the methods and data used in the study, which includes the case study area, data sources and processing. Section 4 presents the results of the empirical analysis, which are divided into three parts: a description of the paradox between rural population decline and cultivated land expansion, the exploration of the mechanisms 
behind cultivated land expansion, and the exploration of the impact of cultivated land expansion. Our conclusion and discussion are presented in Section 5.

\section{Background and Research Framework}

\subsection{Diversified Cultivated Land Protection Policies}

Many countries have tried various policy tools to protect cultivated land, including regulatory tools (such as agricultural zoning and urban growth boundaries), the purchase of development rights programs (PDR), the transfer of development rights (TDR) programs, and tax incentives tools [40-42]. Several studies have attempted to evaluate the effects of these policies on cultivated land protection. For example, Stoms et al. (2009) have evaluated the PDRs program in the United States [40], while Nixon and Newman (2016) have assessed the efficacy and politics of land use regulation on farmland preservation in the United Kingdom [42], and their findings have shown that these policies have been relatively successful in protecting cultivated land. However, each country has its own cultivated land use and policy system contexts, and these tools may not be applicable to other contexts [43]. Choosing the appropriate cultivated land protection tools or combining them may help to obtain enhanced results.

\subsection{The Chinese Cultivated Land Protection Policies}

To ensure food security, the central government of China has established a cultivated land protection system through several regulation tools since the 1990s. The revised version of the Land Administration Law (LAL) in 1998 clearly specified cultivated land protection as a basic national policy. To implement this policy, the central government formulated a land use master plan (LUMP) at the national level which clarifies the specific tasks and objectives of the cultivated land protection over a certain period of time (generally 15 years). The LAL requires the provincial, prefectural, and county-level units to formulate their own LUMP by fully considering the cultivated land-related tasks from the superior LUMP, including the cultivated land retention quota and supplement quota $[32,44]$.

The central government can supervise and urge local governments to practice and achieve the tasks of cultivated land protection in the LUMPs through several regulatory policy tools: (1) the provincial units should designate $80 \%$ of their cultivated land as basic farmland, which should be reserved permanently in principle; (2) they should strictly examine and approve the conversion of cultivated land to constructive land; (3) according to the "dynamic balance of total cultivated land (DBTCL)" policy, local governments should achieve a dynamic balance of the total cultivated land by compensating for the loss of cultivated land; (4) carrying out projects to consolidate and develop cultivated land to increase the amount of cultivated land [34,36].

These policy tools may have played an important role in preventing the loss of cultivated land and the spontaneous occurrence of urban sprawl [45]. However, these policy tools cannot regulate the decisions of the farmers. Many cultivated land parcels have been abandoned due to low returns and agricultural labor shortage caused by the large-scale rural population outmigration $[16,18,46,47]$. Moreover, under China's land property rights system, rural households only own the right to use rural land rather than the actual land itself, which is carried out via long-term contracts (around 30 years) [48]. However, rural households have no right to sell their contracted land in the land market, which further contributes to the abandonment problem $[23,49]$. While the central government has implemented a series of agricultural subsidies encouraging farmers to cultivate their land and improve grain yield, the effects are far from satisfactory [50,51].

To prevent further abandonment of cultivated land, the central government carried out the land transfer policy of rural lands in 2014. The "separating three property rights" reform has divided the land ownership type into outright land ownership, non-tradable contractual rights, and tradable land usage rights [52]. While the land transfer policy does not change land ownership, nor contractual rights, it does allow rural households to trade their land usage rights to other rural households, village collective cooperatives, and 
agricultural enterprises; however, these new actors are forbidden to change the land use type $[23,24]$. The central government has promised to support the transfer of agricultural lands (especially cultivated lands) to promote better land scale management. Since then, the central and local governments have issued a series of policies to encourage and guide rural households to voluntarily transfer rural land. Therefore, the land transfer policy has been one of the most important reforms of rural agricultural land use in recent years.

All in all, the Chinese central government has attempted to build and improve the policy system of cultivated land protection to prevent the decline of cultivated land. The regulatory policy tools can strongly constrain the cultivated land occupation of local governments and urge them to preserve cultivated land. The central government have also attempted to employ non-regulatory policies to influence the cultivated land use patterns of rural households. However, these policies and their interactions with each other may induce varied impacts on the change in cultivated land use across regions, which require further discussion $[32,53]$.

\subsection{Research Framework}

In the Chinese context, there are three main actors in the process of cultivated land use, namely the central government, the local governments, and the rural households (Figure 1). These actors play different roles in the process of cultivated land use: the central government is the firm defender of cultivated land and the top policymaker, the local governments are the executors of the central government's cultivated land protection policies and the director of local economic and social development, while rural households are the owners of cultivated land use rights and decision-makers of cultivated land use.

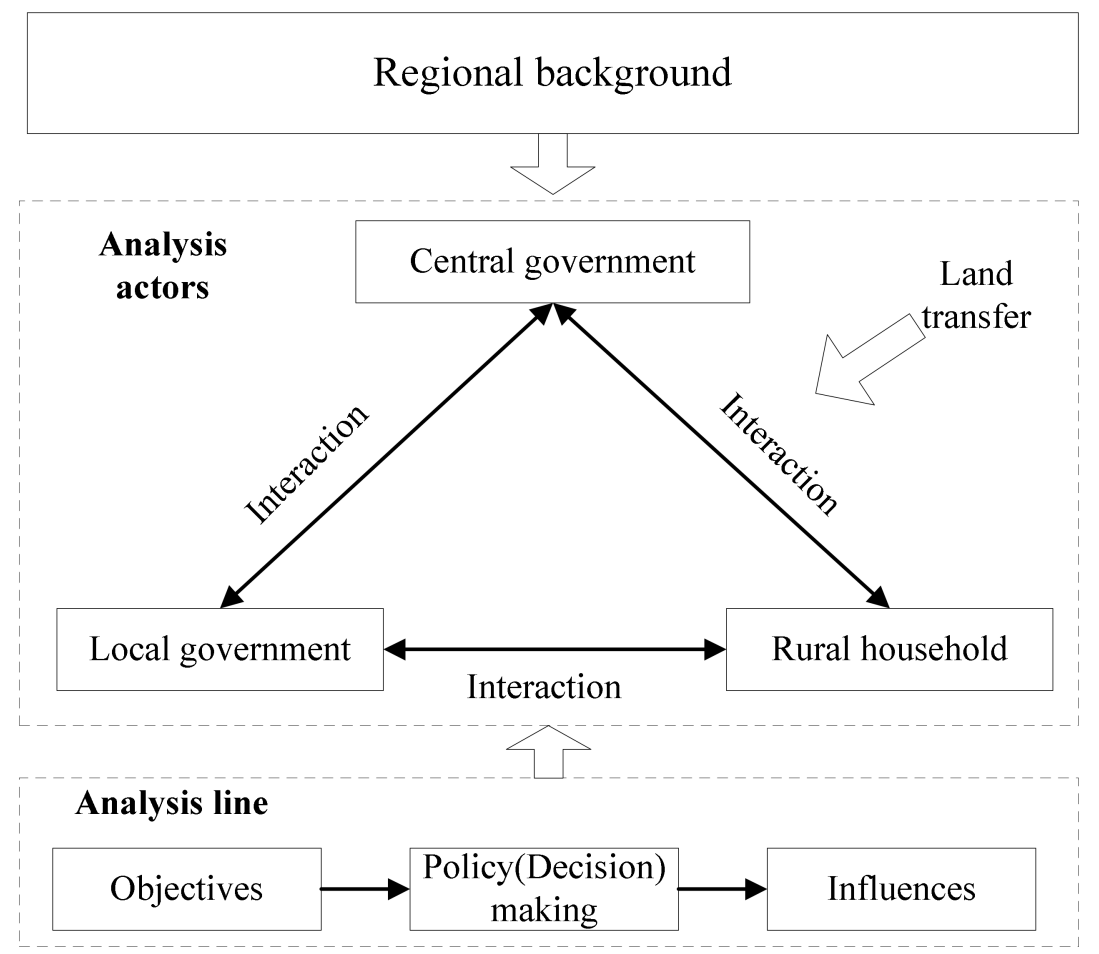

Figure 1. The research framework of the mechanism of cultivated land expansion.

These actors have different objectives in the process of cultivated land use, and thus they may have different attitudes toward cultivated land protection, which may determine their policies or decisions on cultivated land use. These policies or decisions can influence the cultivated land use patterns and environmental change, water use, and other aspects. These influences can in turn affect the policies or decisions of other actors, which may prompt them to adjust their policies or decisions to achieve their objectives. The implemen- 
tation of the land transfer policy may change the previous decisions of rural households on cultivated land use, which may, in turn, affect the previously established interaction relationship of the other actors. Thus, analyzing the decision changes of rural households after the implementation of the land transfer policy and the corresponding responses of the central government and local governments will help to reveal the mechanism of cultivated land change.

Regional backgrounds can affect the attitudes and decisions of local governments and rural households regarding the protection and use of cultivated land, which may lead to regional differences in the performance of cultivated land use policies. These regional backgrounds may include natural environmental factors, such as soil conditions, land use types, water resources, and so on, and economic factors, such as rural employment opportunities and income level. The special regional backgrounds in the farming-pastoral ecotone may be important to understand the role of land transfer on cultivated land expansion in the context of rural population decline.

\section{Method and Data}

\subsection{Case Study of Taibus Region}

The farming-pastoral ecotone is a transition zone that connects the grassland livestock region and the farming areas. In 2016, China's Ministry of Agriculture released the scope of the farming-pastoral ecotone, which refers to 146 county-level units in eight provincial units (Figure 2$)^{1}$. In this study, we will use Taibus, a typical area in the farming-pastoral ecotone, as a case to investigate the phenomenon of cultivated land expansion and its underlying mechanism.

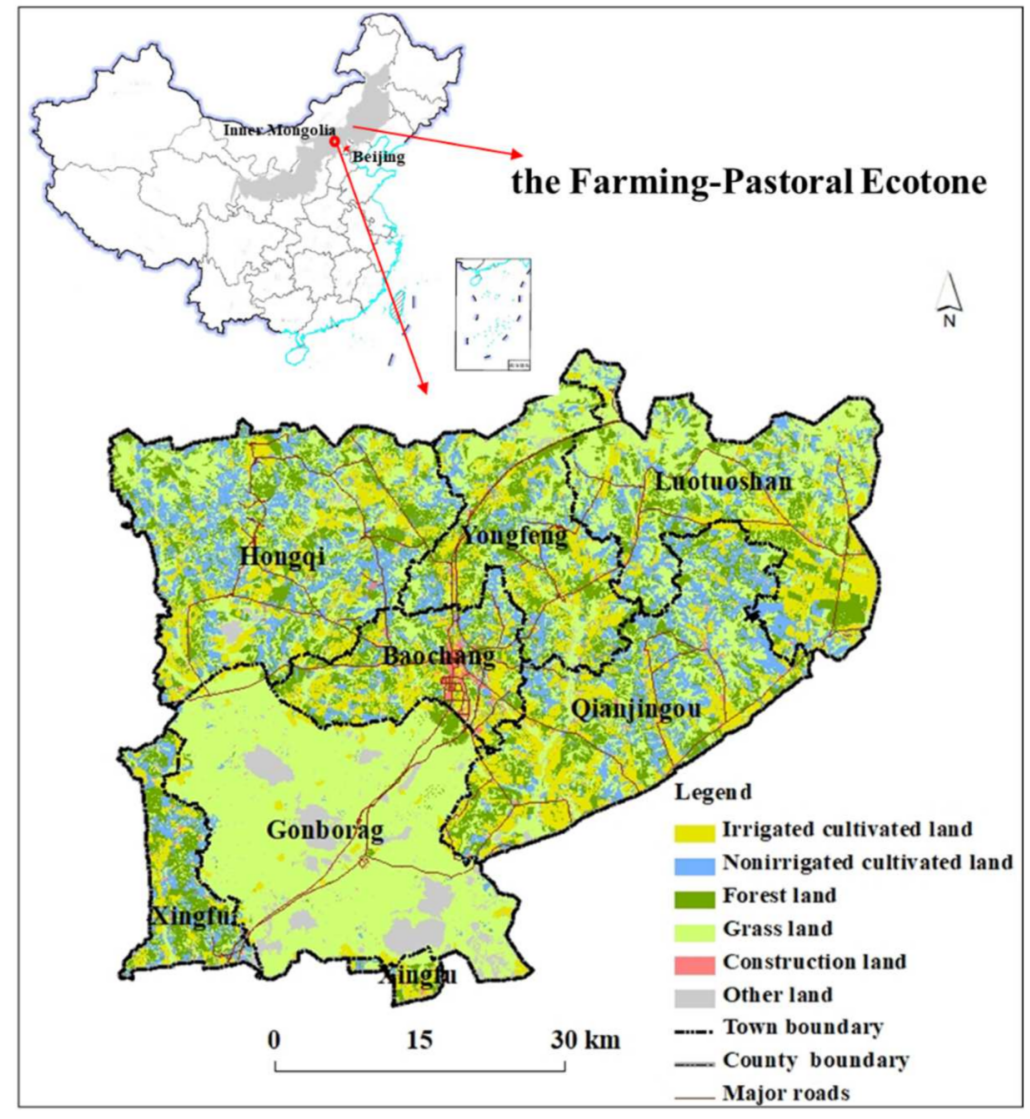

Figure 2. The location of Taibus.

Taibus is a county-level unit, located in the central part of Inner Mongolia. It contains six towns/townships and one Sumu (Gonborag, a town level unit completely belonging 
to the grassland livestock region). In 2019, Taibus occupied an area of approximately $342,614.88$ ha, with cultivated land, forest land, and grassland accounting for $31.1 \%, 18.5 \%$, and $43.5 \%$ of that area, respectively. Taibus has scarce water resources, with an average of 135 million cubic meters of water annually. A majority of these water resources are groundwater resources $(76.3 \%)$. The water resource per capita in Taibus is $658 \mathrm{~m}^{3}$, which is much lower than the international standard for severe water shortage $\left(1000 \mathrm{~m}^{3}\right)$.

Taibus has a total permanent resident population of 109,400 in 2020, and a rural population of 59,800. Even though Taibus is not a well-developed region economically, it still achieved a 6.1\% increase in regional Gross Domestic Product (GDP) in 2019. Unfortunately, per capita GDP was only 38,932 Yuan, which is much lower than the national average level of 70,892 Yuan. Agriculture is still important for economic development in Taibus, which accounted for $29.8 \%$ of the total GDP and contributed to $51.3 \%$ of the economic growth in 2019.

\subsection{Data Sources and Processing}

This study contains population data, land use data, economic data, and water resource data. The population data was derived from the 2000 and 2010 population census data of China, and the main data bulletin of the Seventh Census of Taibus. The land use data was supplied by the Data Center for Resources and Environmental Sciences at the Chinese Academy of Sciences (RESDC). The land-use data is raster data with a resolution of $100 \times 100 \mathrm{~m}$, which contains information on construction land, cultivated land, forestland, grassland, water, and unused land [54]. We have used ArcGIS 10.7 to analyze the cultivated land spatial change. The economic related data, including GDP and per capita income of rural households, and planting structure, was obtained from the annual statistical yearbook/bulletin supplied by the Taibus Bureau of Statistics. The national level data were collected from the China Statistical Yearbook. The water resource data were collected from the annual water resources bulletin of Taibus.

\section{Results of Empirical Analysis}

\subsection{The Paradox between Rural Population Decline and Cultivated Land Expansion}

Taibus has experienced significant net rural outmigration, that is, the number of rural permanent residents (the de facto population) was much lower than the Hukou population (or the registered population) in the past decades. The net outmigration rate was about $20 \%$ in 2000 , but it soared to $56.8 \%$ in 2010 and increased all the way up to $64.3 \%$ in 2020 . Rural population outmigration is primarily due to low agricultural production returns, and they have migrated to developed regions in search of better job opportunities and higher incomes [55]. Moreover, the number of rural permanent residents have also declined from about 140,000 in 2000 to about 73,600 in 2010, and to only 59,800 in 2020 (Figure 3). The majority of the out-migrating rural population was from the working-age population. Therefore, the size of the labor population (aged from 15 to 64 ) declined from about 100,000 in 2000 to about 55,000 in 2010, and then to about 40,000 in 2020 for a total decline size of about 60,000 , which accounted for $75 \%$ of the total rural population decline from 2000 to 2020.

Although the rural population and the labor force have significantly decreased, the area of cultivated land in Taibus has continued to grow from 2010 to 2019, especially in the northern region (Figures 4 and 5). The total area of cultivated land was almost stable from 2010 to 2014, but it increased from about 100,000 ha to more than 110,000 ha from 2014 to 2019 , which was an increase percentage of over $10 \%$ in five years. The area of irrigated cultivated land increased from 12,700 ha in 2010 to about 50,000 ha in 2019. In contrast, nonirrigated cultivated land has been decreasing, from 87,500 ha in 2010 to about 61,900 ha in 2019. This could be due to the Taibus government promoting the construction of irrigation facilities, and rural households abandoning some of the non-irrigated cultivated land with low yields. 


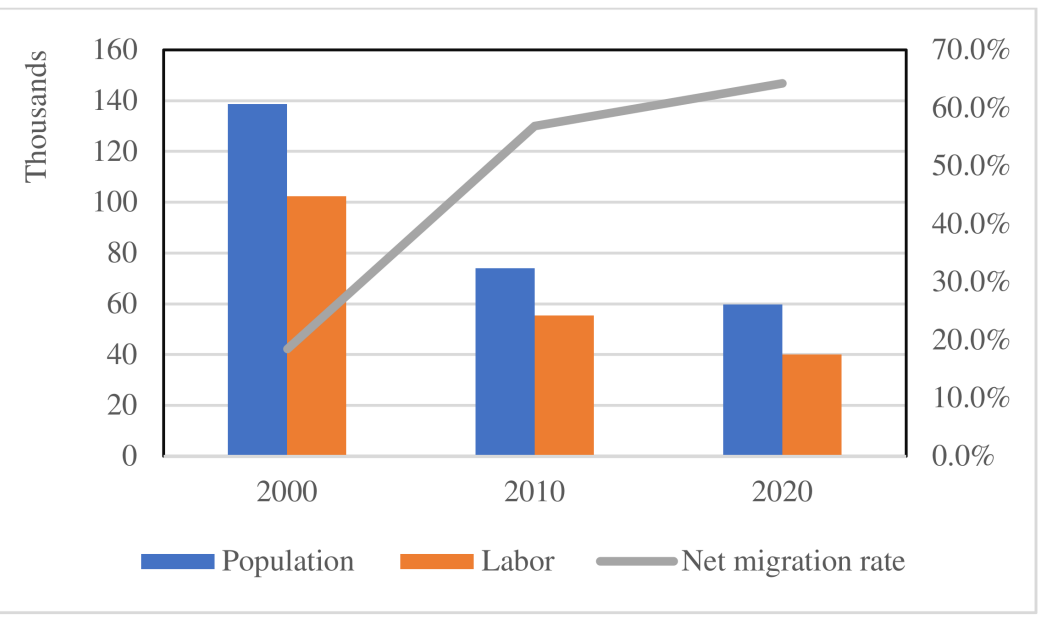

Figure 3. Rural population change in Taibus from 2000 to 2020.

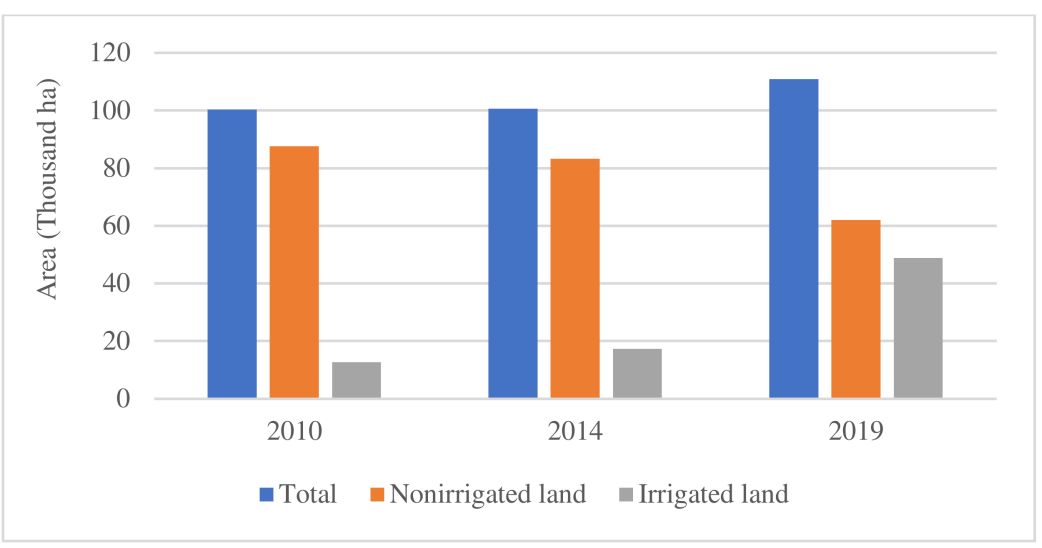

Figure 4. The changes in cultivated land area in Taibus from 2010 to 2019.

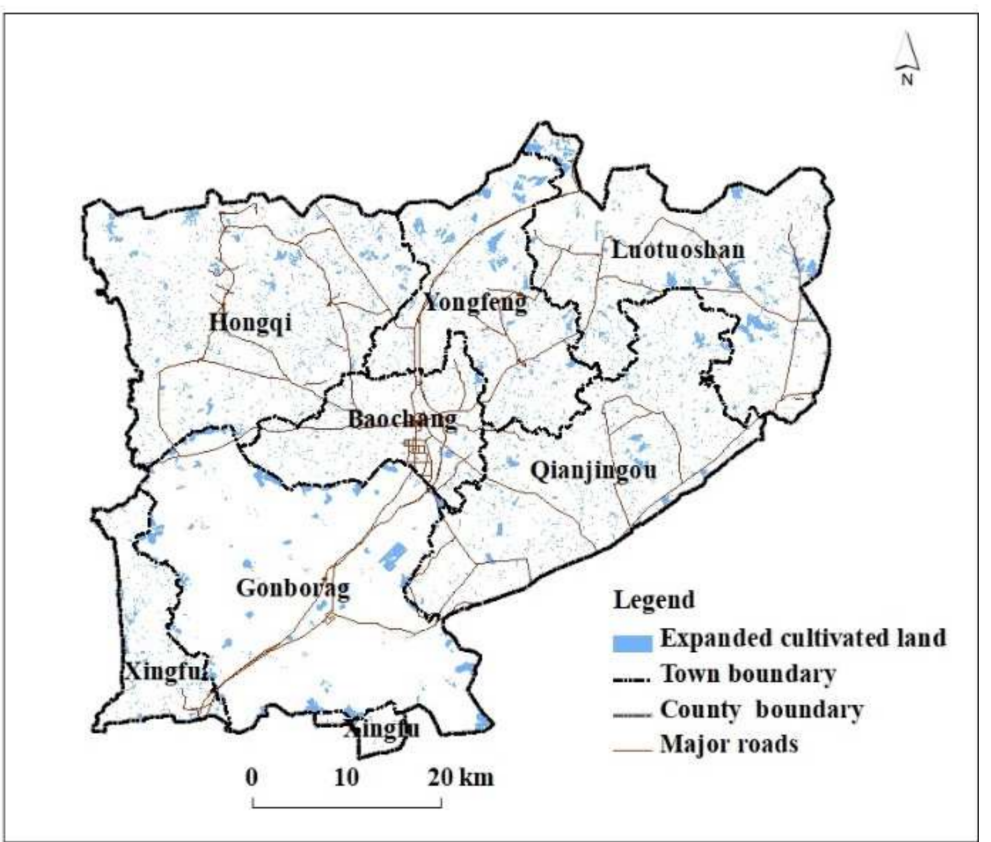

Figure 5. The distribution of the expanded cultivated land from 2010 to 2019. 
4.2. Exploring the Mechanism of Cultivated Land Expansion in the Rural Population Decline Context from a Policy Analysis Perspective

4.2.1. Different Objectives of the Actors in Cultivated Land Use

(1) The central government

To ensure food security, the central government proposed a cultivated land red line of 120 million ha in 2013. To achieve this aim, cultivated land protection tasks were assigned to each provincial-level unit in the "Outline of National Land Use Master Plan (2006-2020)". However, China's cultivated land preservation policy took a one-size-fits-all approach and demanded the same level of cultivated land protection in all regions, partly because they had to balance the interests of the local governments. The area of land assigned protection in Inner Mongolia was no less than 6.97 million ha cultivated land in 2020 when the total cultivated land of Inner Mongolia was only 7.10 million ha in 2006, which indicates that the central government did not lower their requirements for Inner Mongolia or consider the poor quality of cultivated land in this region. Thus, the objective of the central government in the farming-pastoral ecotone is nothing special compared with other regions, namely, to protect cultivated land as much as possible.

\section{(2) Local governments}

The local governments have several administrative levels, namely the provincial, the prefectural, and the county level governments. Because Taibus is a county-level unit, the provincial and the prefectural governments play the role of supervisors in the processes of cultivated land use in Taibus. In contrast, the Taibus local government is the direct policy executor, and it has multiple objectives which affect policy implementation and decisionmaking in the cultivated land use process. The top priority of the Taibus government is economic growth, which determines the promotion of local government officials. To achieve high economic growth, the local government has a strong incentive to convert cultivated land into construction land, which is an important driver of cultivated land decline. However, achieving the task of protecting no less than 89,311 ha of cultivated land assigned by the prefectural government is also something they need to consider. In addition, an important duty of the local government is to improve the income of the rural inhabitants, which is important for rural development and eliminating poverty.

\section{(3) Rural households}

The main objective of the rural households who stay in rural areas is attaining maximum income through agricultural lands using two common ways: one is making full use of the existing cultivated land resources, such as changing the cultivation pattern or improving crop yields, which may require labor, capital, and new agricultural technology. The other way is the conversion of low-return land types to high-return ones, which mainly refers to the conversion of grass and forest land to cultivated land, which requires intensive labor. Rural households will consider various factors, including the cultivated land policy, environment, market, and household related factors when deciding on agricultural land use.

\subsubsection{The Decision-Making Processes of the Actors without and with Land Transfer}

We will discuss the decision-making processes of the actors in two situations (Figure 6): one without land transfer, and the other with land transfer. Comparing these two situations will help us understand the expansion process of cultivated land and the role of land transfer in the context of rural population decline. 


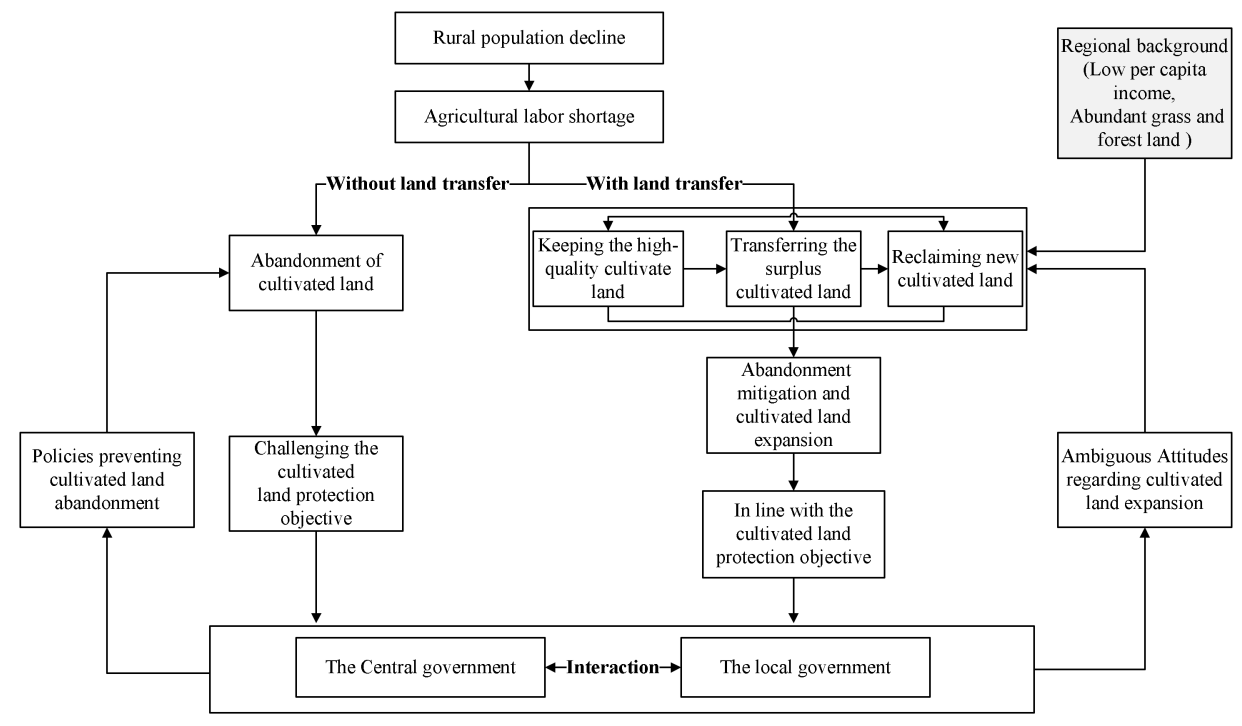

Figure 6. Two situations of cultivated land change without and with land transfer.

(1) Situation 1: Cultivated land change without land transfer

The labor outmigration in rural areas has led to a shortage of rural household labor, while those among the individuals that remain are significantly older in age. Although agricultural production technology has significantly improved over the past few decades, agricultural production is still a challenge for an ageing labor force. Thus, in the context of a declining rural population, there is a high possibility that rural households will keep high-quality cultivated land and abandon low-quality ones. In 2010 , about $11 \%$ of the cultivated land in Taibus had been abandoned. While some rural households may still reclaim cultivable land to gain more income, its influence on cultivated land expansion is limited.

Land abandonment has caused the wastage of cultivated land resources, which has challenged the cultivated land protection objective of the central government. Thus, the central government has released a series of policies to prevent cultivated land abandonment at the national level (as mentioned in Section 2.1). Although these policies are solely directed against at the Taibus region, the local government has been pressured by their superiors, which has led to the implementation of policies preventing cultivated land abandonment, such as encouraging land transfer of rural households, improving the agricultural infrastructure, and providing production subsidies. For example, the local government injected more than 7.26 million yuan to help 362 rural households purchase agricultural production machineries in 2010. Moreover, the local government also proposed the plan to replenish more than 200 ha cultivated land via DBTCL, rural homestead renovation, and ecological restoration.

In short, to achieve the cultivated land protection objectives, the central and local governments have been cautious about the abandonment and loss of cultivated land, leading to measures or policy adjustments to prevent or eliminate the above situations.

(2) Situation 2: Cultivated land change with land transfer

The introduction of land transfer has significantly affected the decision making of rural households in rural land use. Cultivated land is now an asset that can earn profits when the rights of use can be transferred, which increases the number of ways in which cultivated land can benefit rural households. Thus, in light of the agricultural labor shortage, rural households now have more choices to enhance their income. According to our survey data, the land transfer fee was about 7500 Yuan per ha for high-quality cultivated land (usually referring to the irrigated land), and about 4500 Yuan per ha for low-quality land ${ }^{2}$. Nonetheless, the land transfer fees are lower compared to the profits that could be generated if rural households choose to work on the cultivated land themselves. Thus, 
some rural households may choose to work on part of their cultivated land by making use of their existing labor forces. Then, they can transfer their surplus cultivated land to other cultivated land receivers, which helps solve the labor shortage problem of rural households in agricultural production. The data shows that $19.82 \%$ of total cultivated land was transferred in 2015, which increased to about $29.6 \%$ in 2018 , and even up to $60 \%$ in some towns with high quality cultivated land, such as the Luotuoshan and Qianjingou. Land transfer has helped prevent cultivated land abandonment, with the abandonment rate declining to about $4.8 \%$ in $2019^{3}$.

Additionally, the benefits of land transfer have also encouraged rural households to reclaim more cultivable land as the costs of reclaiming new land are low and rural households no longer need to invest in irrigation facilities, as the local government and the cultivated land receivers will build these facilities through their constructive planning. Official data showed that the local government had constructed 576 wells for agricultural irrigation from 2010 to 2019. Consequently, cultivated land reclamation activities have spread in recent years. The size of newly reclaimed cultivated land was more than 140,000 ha from 2014 to 2019, and the per household cultivated land area in Taibus increased from about 2.6 ha to 3 ha.

Cultivated land expansion has ever aroused the attention of the central government because of the soil erosion problem in the 2000s, which led to the launch of a project returning cultivated land to forest land [21,49]. However, this project was phased out around 2010 as the return of cultivated land has been the leading reason of cultivated land reduction, which has threatened the central government's objective of cultivated land protection. Since the 2010s, the stability and the moderate expansion of cultivated land have been consistent with the expectations of the central government, while the possible negative impacts and risks of cultivated land expansion have not been the biggest concern of top policymakers. Although the problem of soil erosion still exists in Inner Mongolia, cultivated land expansion has not encountered much policy constraints from the central government.

The expansion of cultivated land will occupy grass and forest land areas, which is prohibited by the related laws. However, the local government has no strong willingness to investigate and restrain the reclamation behaviors of rural households. First, the cultivated land reclamation activity of households can make up for the reduction of cultivated land caused by construction land expansion and help the local government achieve their cultivated land protection task. Second, the top priority of the local government is promoting economic growth, and they will not waste resources investigating cultivated land expansion before the central government does. Third, cultivated land expansion can improve the income level of rural households, which can help eliminate rural poverty and maintain social stability. In short, the expansion of cultivated land benefits instead of threatening the interests of the local government, which is why local government tends to be ambiguous toward the reclamation activities of rural households.

\subsubsection{The Influences of Regional Background}

Land transfer is not necessary for cultivated land expansion, and the relationship between land transfer and cultivated land change can be closely related to the regional background. Two aspects of the regional background are important for the expansion of cultivated land in Taibus. First, the economic development and per capita income of rural households are low. There are few industries in rural areas, so most rural residents rely heavily on agricultural income. The per capita income of rural households is lower than the national average and much lower than that of the coastal region (Figure 7). Although the land transfer fee per ha is not high, rural households can still obtain considerable income due to the high level of cultivated land per capita in Taibus. Thus, the income from the land transfer can be attractive to rural households and can also incentivize them to reclaim cultivated land. 


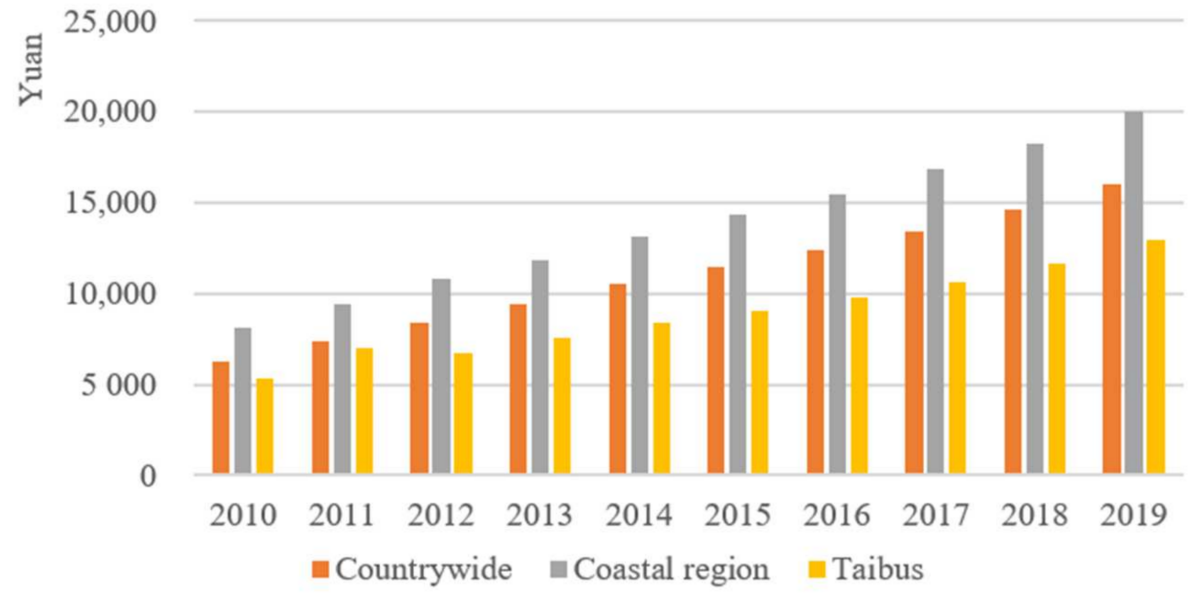

Figure 7. The per capita income of rural population in Countrywide, the Coastal region and Taibus from 2010 to 2019.

Second, Taibus has abundant grass and forest land reserves which can be reclaimed as cultivated land. The total percentage of forest and grass lands is over $60 \%$, with most of them in good condition to be converted to cultivable land due to being located near the village, the availability of groundwater, and accessibility to the existing cultivated land. This satisfies the most important external conditions for cultivated land expansion. In fact, most of the newly cultivated land were converted from grass land (Figure 8). In contrast, rural households in some traditional agricultural areas may also have the same incentive to reclaim more cultivated land, but there may be no more land available for reclamation activities.

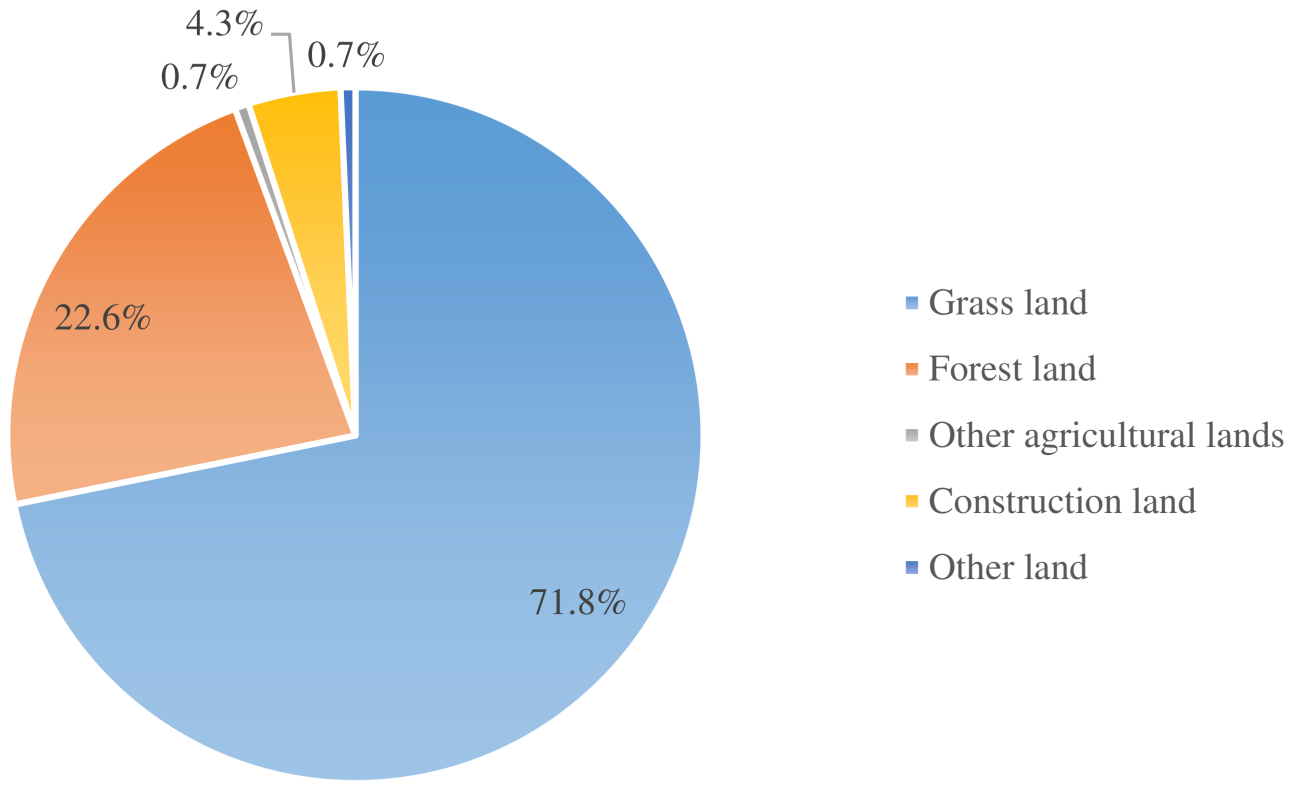

Figure 8. The sources of the new cultivated land.

4.3. The Impacts of Cultivated Land Expansion and Land Transfer in the Farming-Pastoral Ecotone 4.3.1. Positive Impacts

As mentioned in Section 4.2.2, cultivated land expansion can increase the income of rural households and supply seasonal/temporary employment opportunities and permanent ones, which can help in improving their living conditions. There is no official data on the land transfer income for rural households, but the official data shows that the average wage income for rural households that still remain in the rural areas have increased from 
1188 Yuan in 2010 to 5360 Yuan in 2019, thus indicating that it is now a significant part of their total income (Figure 9). This can partly reflect the contribution of the jobs related to land transfer on rural households' income growth because industrial job opportunities in rural Taibus are still quite limited.

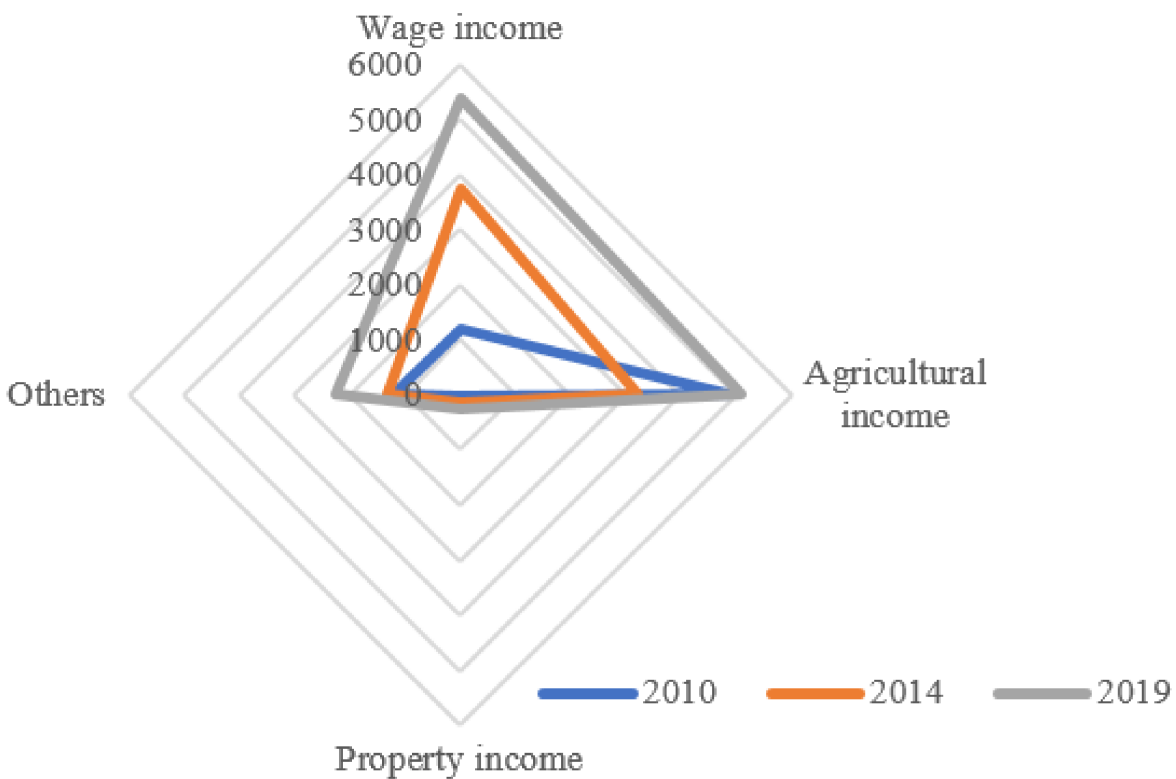

Figure 9. The per capita income structure change of rural household in Taibus from 2010 to 2019.

Previous studies have shown that land transfer can effectively alleviate the problem of cultivated land abandonment. Without land transfer, some cultivated land may also be abandoned by rural households due to labor shortage in Taibus. Moreover, land transfer helps achieve large-scale cultivation of cultivated land, which can improve cultivated land productivity by applying advanced agricultural technology.

\subsubsection{Negative Impacts and Risks}

There are a few negative impacts from cultivated land expansion. First and foremost, there is the serious overuse of groundwater resources. Not only is Taibus short of water resources, but there is also no surface water all year round, and so the water supply is mainly derived from groundwater. Although water conservation facilities have been constructed and promoted in recent years, the expansion of cultivated land has still increased agricultural water consumption. The total water consumption of Taibus was 45.49 million $\mathrm{M}^{3}$ in 2018, with agricultural water consumption around 39.30 million $\mathrm{M}^{3}(86.4 \%)$. The total water consumption of Taibus has increased to 52.76 million $\mathrm{M}^{3}$ in 2019 (an increase of 7.27 million $\mathrm{M}^{3}$ ) and this was mostly due to the increase in agricultural water consumption. The groundwater in some areas with large-scale cultivated land has been overexploited, and the depths of many wells supplying water for agricultural production have exceeded $100 \mathrm{~m}$. This has caused a decrease in groundwater levels and the formation of a shallow groundwater funnel. Simultaneously, it may change the characteristics of the water cycle, which may affect the open water surfaces and even the sea-level [56]. More importantly, the impact of the long-range dependence behavior of the water-cycle, which is known as the Hurst phenomenon, may bring extreme droughts, temperatures, and precipitations on a long-term basis $[57,58]$. These negative impacts may in turn produce profound impacts on cultivated land use in the near future.

Second, cultivated land expansion will increase the risk of land desertification. Most of the soil in Taibus is chestnut soil and light chestnut soil, which offers little corrosion resistance. Moreover, during the dry season, Taibus is often besieged by strong winds, which intensifies wind erosion and risks soil desertification. Thus, once the natural vegetation is 
destroyed, desertification will rapidly be hastened by the strong winds. Cultivated land reclamation, especially that in hilly and gully areas, will inevitably destroy soil vegetation, cause the decline of water and soil conservation capacity, and exacerbate soil and water loss. This situation will become even worse after the cultivated land is abandoned.

The third negative impact concerns the possible overuse and abandonment of cultivated land in the land transfer processes. Land transfer contracts are often short-term, which rural households and cultivated land receivers may renew as they see fit. The objective of cultivated land receivers is to maximize their profits, and they may not have a sustainable plan for the long-term use of cultivated land. This may bring a series of problems, such as maximizing tillage and the large-scale use of chemical fertilizers and plastic films, and overuse of the groundwater. Once the land transfer receivers face the decline in cultivated land fertility and the insufficiency of irrigation water, they may no longer renew their land transfer contract, and many cultivated land parcels may be inevitably abandoned due to the shortage of labor forces in rural areas.

\subsubsection{Uncertain Impacts}

Land transfer has uncertain impacts. Land transfer has affected the planting structure in Taibus. To achieve more profits, the land transfer receivers have a strong incentive to plant non-grain crops. In 2010, about $69.8 \%$ of the cultivated land was planted with grain crops, followed by vegetable (about $10.6 \%$ ) and oil crops (about $9.8 \%$ ). The percentage of grain crops saw a slight growth in 2014, before decreasing to $64.8 \%$ in 2019. In contrast, the percentage of oil crops has increased to about $16.0 \%$ in 2019, while the areas cultivating feed and traditional Chinese medicine crops have also increased from 2010 to 2019 (Figure 10). Changes in planting structure can bring more profits for the land transfer receivers and rural households. Based on this, the local government has encouraged and supported changes in the planting structure, which may well continue in the future. However, the nongrain trend of cultivated land is contradictory to the objectives of the central government as the final objective of protecting cultivated land is to ensure food security. Thus, the change in the planting structure may have different impacts on the objectives of different actors in the cultivated land use processes, and it may be difficult to draw a conclusion on these impacts at present.

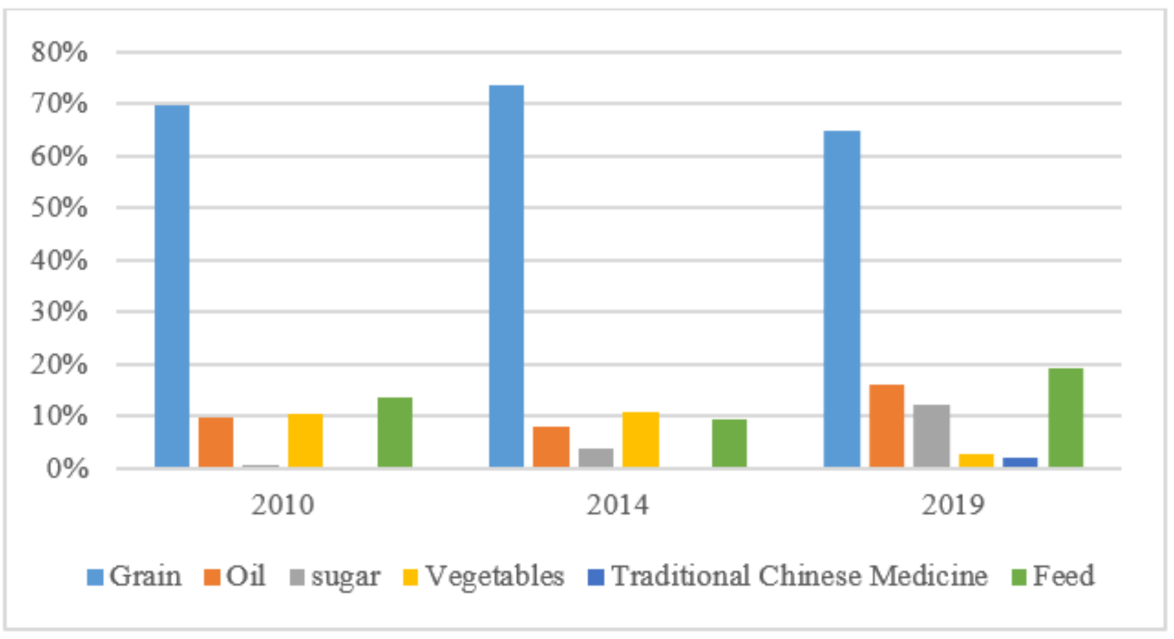

Figure 10. The changes in planting structure in Taibus from 2010 to 2019.

Overall, although cultivated land expansion has a varied impact in several aspects, the negative impact and risks should be given priority by all actors in the cultivated land use processes, given the serious water shortage and fragile ecological environment of the farming-pastoral ecotone. These negative impacts and risks may far outweigh the benefits of the current expansion of cultivated land, and they may affect the long-term sustainable development of Taibus. 


\section{Conclusions and Discussion}

While many regions in China have experienced cultivated land abandonment and loss with a continuously declining rural population, there is a paradox regarding rural population decline combined with cultivated land expansion in the farming-pastoral ecotone. Taibus has a population decline of up to 64.3 percent in 2020, according to our findings; however, cultivated land has increased by more than $10 \%$ in the past five years. Land transfer policy has played an important role in promoting cultivated land expansion, because land transfer can effectively solve labor shortages and the problem of lack of agricultural facility inputs of rural households in cultivated land use, while also encouraging them to reclaim cultivated land. Under China's cultivated land protection system, cultivated land expansion apparently aligns with the interests of the central and local governments, which has resulted in ambiguous attitudes and a lack of strict policies to prevent the reclamation activities. Moreover, two aspects of regional background, including the low per capita income of rural households and the abundant grass and forest land in the farming-pastoral ecotone, have also contributed to the promotion of cultivated land expansion. The expansion of cultivated land may have improved rural household income, but it has led to an increase in agricultural water consumption of 7.27 million M3 in the past two years. This has put a strain on the limited water supply and the vulnerable environment.

Previous studies have found that population growth and rising food demand are the primary drivers of cultivated land expansion in many regions [11,12]. In this study, our findings imply that the significance of agricultural land use policies in cultivated land expansion should not be overlooked. Moreover, our findings contribute to a better understanding of how land use policies perform in different regional contexts. While most studies have focused on the impact of land transfer in preventing land abandonment in the context of a declining rural population, this study has found that land transfer can also lead to the expansion of cultivated land, which can have a negative impact on the environment in some regions $[17,28,29,39]$. The land transfer policy in China has some similarities with the PDR and TDR programs in the United States; however, to our knowledge, there is no evidence that these programs have resulted in cultivated land expansion [40,41]. These disparities can be attributed to inadequate supervision of grassland and forestland protection in the Chinese context over the last decade, thereby providing opportunities for cultivated land reclamation [39].

Based on our findings and the discussions above, we can draw some policy implications for cultivated land use and regional sustainable development. We suggest that the central government pay more attention to cultivated land expansion and the related negative impacts on the ecological environment in the farming-pastoral ecotone and other ecologically fragile areas. First, the central government may need to adjust their one-sizefits-all approach to cultivated land protection. It would be better to reduce the scope of cultivated land protection in the ecologically fragile areas, given their poor quality of cultivated land, the limited water resources, and the high risk of ecological deterioration. The evaluation of the quality of cultivated land and carrying capacity of water resources for agricultural production may be useful for determining a reasonable quantity of cultivated land to protect. This can ensure that local governments will face the phenomenon of cultivated land expansion and its possible impacts in a rational manner.

Second, the central government may need to enact stricter policies and measures to limit cultivated land expansion in ecologically fragile areas. Cultivated land reclamation from grass and forest land should be strictly restricted, while reclaimed cultivated land should be returned to their original land types, especially in areas with overloaded water resources and ecological degradation. Moreover, we suggest that the central government should pay attention to the impact of land transfer on cultivated land expansion, and that it may be necessary to limit the transfer of newly reclaimed cultivated land. Considering the low income of rural households in these regions, the central government can consider giving more agricultural subsidies and increasing the investment in poverty alleviation, which may help eliminate rural households' motivation to reclaim cultivated land. 
We suggest that local governments approach cultivated land expansion from a sustainable development perspective. While it is true that cultivated land expansion can help achieve the local government's cultivated land protection task and improve rural household income in the short term, the negative impact and risks of cultivated land expansion and land transfer should not be overlooked, particularly the long-term negative impacts of groundwater overexploitation, which may affect sustainable cultivated land use and the ecological environment. Therefore, the local government may need to change their ambiguous attitude on cultivated land expansion and pay more attention to the related problems and risks. First, the local government should more strictly supervise the reclamation of cultivated land and implement grassland and woodland conservation policies. Second, they must fully assess regional water resource pressures and take measures to optimize water resource utilization at county and town levels, such as controlling total water consumption and limiting groundwater overexploitation, increasing the percentage of ecological water, and facilitating the construction of water-saving facilities. Third, the local government needs to strengthen the supervision of cultivated land use by the land transfer receivers, including limiting the overuse of cultivated land, assessing the cultivated land quality at the end of the land transfer contract, and preventing excessive planting structure changes. All in all, we suggest that the local government target a balance between cultivated land use and ecological protection, while paying more attention to the sustainable use of cultivated land.

Finally, this study has certain limitations. The causes of cultivated land expansion were only analyzed from a policy perspective; other factors should be addressed in future studies. Moreover, employing some quantitative analysis methods and conducting more empirical studies in other regions may help to further solidify the findings of this study.

Author Contributions: Conceptualization, methodology, writing-original draft preparation, writing-review and editing, funding acquisition, Z.L. Author has read and agreed to the published version of the manuscript.

Funding: This study was funded by the National Natural Science Foundation of China, grant number No. 42001166.

Institutional Review Board Statement: Not applicable.

Informed Consent Statement: Not applicable.

Data Availability Statement: No new data were created in this study. Data sharing is not applicable to this article.

Conflicts of Interest: The authors declare no conflict of interest.

\section{Notes}

1 The official scope of the Farming-Pastoral Ecotone in northern China can be found in the following website: http:/ /www.moa. gov.cn/nybgb/2016/shierqi/201711/t20171125_5919525.htm (accessed on 6 January 2022).

2 In 2020, we interviewed the governors of the six towns/townships about the cultivated land transfer fee in recent years.

3 According to our interview with rural households, most of the abandoned land was non-irrigated land which were relatively far away from the villages, and these lands were generally not easily transferrable.

\section{References}

1. Kassis, G.; Bertrand, N.; Pecqueur, B. Rethinking the Place of Agricultural Land Preservation for the Development of Food Systems in Planning of Peri-Urban Areas: Insights from Two French Municipalities. J. Rural Stud. 2021, 86, 366-375. [CrossRef]

2. Fazal, S. Urban Expansion and Loss of Agricultural Land-A GIS Based Study of Saharanpur City, India. Environ. Urban. 2000, 12, 133-149. [CrossRef]

3. Cheng, L.; Jiang, P.; Chen, W.; Li, M.; Wang, L.; Gong, Y.; Pian, Y.; Xia, N.; Duan, Y.; Huang, Q. Farmland Protection Policies and Rapid Urbanization in China: A Case Study for Changzhou City. Land Use Policy 2015, 48, 552-566. [CrossRef]

4. Baumann, M.; Kuemmerle, T.; Elbakidze, M.; Ozdogan, M.; Radeloff, V.C.; Keuler, N.S.; Prishchepov, A.V.; Kruhlov, I.; Hostert, P. Patterns and Drivers of Post-Socialist Farmland Abandonment in Western Ukraine. Land Use Policy 2011, 28, 552-562. [CrossRef] 
5. Nelson, A.C. Preserving Prime Farmland in the Face of Urbanization: Lessons from Oregon. J. Am. Plan. Assoc. 1992, 58, 467-488. [CrossRef]

6. Queiroz, C.; Beilin, R.; Folke, C.; Lindborg, R. Farmland Abandonment: Threat or Opportunity for Biodiversity Conservation? A Global Review. Front. Ecol. Environ. 2014, 12, 288-296. [CrossRef]

7. Liu, L.; Xu, X.; Liu, J.; Chen, X.; Ning, J. Impact of Farmland Changes on Production Potential in China during Recent Two Decades. Dili Xuebao/Acta Geogr. Sin. 2014, 69, 1767-1778. [CrossRef]

8. Meyfroidt, P.; Lambin, E.F. Global Forest Transition: Prospects for an End to Deforestation. Annu. Rev. Environ. Resour. 2011, 36, 343-371. [CrossRef]

9. Li, S.; Li, X. Global Understanding of Farmland Abandonment: A Review and Prospects. J. Geogr. Sci. 2017, 27, 1123-1150. [CrossRef]

10. Liu, Z.; Liu, Y.; Wang, J. A Global Analysis of Agricultural Productivity and Water Resource Consumption Changes over Cropland Expansion Regions. Agric. Ecosyst. Environ. 2021, 321, 107630. [CrossRef]

11. Laurance, W.F.; Sayer, J.; Cassman, K.G. Agricultural Expansion and Its Impacts on Tropical Nature. Trends Ecol. Evol. 2014 29, 107-116. [CrossRef]

12. Chen, D.; Yu, Q.; Hu, Q.; Xiang, M.; Zhou, Q.; Wu, W. Cultivated Land Change in the Belt and Road Initiative Region. J. Geogr. Sci. 2018, 28, 1580-1594. [CrossRef]

13. Ge, D.; Long, H.; Qiao, W.; Wang, Z.; Sun, D.; Yang, R. Effects of Rural-Urban Migration on Agricultural Transformation: A Case of Yucheng City, China. J. Rural Stud. 2020, 76, 85-95. [CrossRef]

14. Long, H.; Tu, S.; Ge, D.; Li, T.; Liu, Y. The Allocation and Management of Critical Resources in Rural China under Restructuring: Problems and Prospects. J. Rural Stud. 2016, 47, 392-412. [CrossRef]

15. Liu, Z.; Qi, H.; Liu, S. Labor Shrinkage and Its Driving Forces in China from 1990 to 2015: A Geographical Analysis. Appl. Spat. Anal. Policy 2021. [CrossRef]

16. Zhang, X.; Zhao, C.; Dong, J.; Ge, Q. Spatio-Temporal Pattern of Cropland Abandonment in China from 1992 to 2017: A Meta-Analysis. Dili Xuebao/Acta Geogr. Sin. 2019, 74, 411-420. [CrossRef]

17. Jiang, M.; Li, J.; Paudel, K.P.; Mi, Y. Factors Affecting Agricultural Land Transfer-out in China: A Semiparametric Instrumental Variable Model. Appl. Econ. Lett. 2019, 26, 1729-1733. [CrossRef]

18. Xu, D.; Deng, X.; Guo, S.; Liu, S. Labor Migration and Farmland Abandonment in Rural China: Empirical Results and Policy Implications. J. Environ. Manag. 2019, 232, 738-750. [CrossRef]

19. Yan, J.; Yang, Z.; Li, Z.; Li, X.; Xin, L.; Sun, L. Drivers of Cropland Abandonment in Mountainous Areas: A Household Decision Model on Farming Scale in Southwest China. Land Use Policy 2016, 57, 459-469. [CrossRef]

20. Zhang, Y.; Li, X.; Song, W.; Zhai, L. Land Abandonment under Rural Restructuring in China Explained from a Cost-Benefit Perspective. J. Rural Stud. 2016, 47, 524-532. [CrossRef]

21. Liu, Y.; Fang, F.; Li, Y. Key Issues of Land Use in China and Implications for Policy Making. Land Use Policy 2014, 40, 6-12. [CrossRef]

22. Li, S.; Li, X. Progress and Prospect on Farmland Abandonment. Dili Xuebao/Acta Geogr. Sin. 2016, 71, 370-389. [CrossRef]

23. Gao, J.; Song, G.; Sun, X. Does Labor Migration Affect Rural Land Transfer? Evidence from China. Land Use Policy 2020, 99, 105096. [CrossRef]

24. Li, A.; Wu, J.; Zhang, X.; Xue, J.; Liu, Z.; Han, X.; Huang, J. China's New Rural “Separating Three Property Rights" Land Reform Results in Grassland Degradation: Evidence from Inner Mongolia. Land Use Policy 2018, 71, 170-182. [CrossRef]

25. Yu, X.; Yin, X.; Liu, Y.; Li, D. Do Agricultural Machinery Services Facilitate Land Transfer? Evidence from Rice Farmers in Sichuan Province, China. Land 2021, 10, 466. [CrossRef]

26. Gao, Y.; Liu, Z.; Li, R.; Shi, Z. Long-Term Impact of China's Returning Farmland to Forest Program on Rural Economic Development. Sustainability 2020, 12, 1492. [CrossRef]

27. Peng, K.; Yang, C.; Chen, Y. Land Transfer in Rural China: Incentives, Influencing Factors and Income Effects. Appl. Econ. 2020, 52, 5477-5490. [CrossRef]

28. Shao, J.; Zhang, S.; Li, X. Effectiveness of Farmland Transfer in Alleviating Farmland Abandonment in Mountain Regions. J. Geogr. Sci. 2016, 26, 203-218. [CrossRef]

29. Zhang, Y.; Li, X.; Song, W. Determinants of Cropland Abandonment at the Parcel, Household and Village Levels in Mountain Areas of China: A Multi-Level Analysis. Land Use Policy 2014, 41, 186-192. [CrossRef]

30. Zhou, T.; Koomen, E.; Ke, X. Determinants of Farmland Abandonment on the Urban-Rural Fringe. Environ. Manag. 2020, 65, 369-384. [CrossRef]

31. Ash, R.F.; Edmonds, R.L. China's Land Resources, Environment and Agricultural Production. China Q. 1998, 156, 836-879. [CrossRef]

32. Lichtenberg, E.; Ding, C. Assessing Farmland Protection Policy in China. Land Use Policy 2008, 25, 59-68. [CrossRef]

33. Liang, X.; Jin, X.; Yang, X.; Xu, W.; Lin, J.; Zhou, Y. Exploring Cultivated Land Evolution in Mountainous Areas of Southwest China, an Empirical Study of Developments since the 1980s. Land Degrad. Dev. 2021, 32, 546-558. [CrossRef]

34. Zhu, H.; Li, Y. An Empirical Analysis of the Causes of Farmland Expansion in Northwest China. Prog. Geogr. 2011, 30, 615-620.

35. Tao, Z.; Wang, S.; Sun, P.; Li, K.; Tian, W.; Han, X. Spatio-Temporal Differentiation and Driving Factors of Cropland in the Agro-Pastoral Ecotone of Northern China. Arid Land Geogr. 2022, 45, 153-163. 
36. Deng, X.; Huang, J.; Rozelle, S.; Zhang, J.; Li, Z. Impact of Urbanization on Cultivated Land Changes in China. Land Use Policy 2015, 45, 1-7. [CrossRef]

37. Cao, Y.G.; Bai, Z.K.; Zhou, W.; Wang, J. Forces Driving Changes in Cultivated Land and Management Countermeasures in the Three Gorges Reservoir Area, China. J. Mt. Sci. 2013, 10, 149-162. [CrossRef]

38. Song, X.; Ouyang, Z.; Li, Y.; Li, F. Cultivated Land Use Change in China, 1999-2007: Policy Development Perspectives. J. Geogr. Sci. 2012, 22, 1061-1078. [CrossRef]

39. Zhou, Y.; Li, X.; Liu, Y. Rural Land System Reforms in China: History, Issues, Measures and Prospects. Land Use Policy 2020, 91, 104330. [CrossRef]

40. Stoms, D.M.; Jantz, P.A.; Davis, F.W.; DeAngelo, G. Strategic Targeting of Agricultural Conservation Easements as a Growth Management Tool. Land Use Policy 2009, 26, 1149-1161. [CrossRef]

41. Dorfman, J.H.; Barnett, B.J.; Bergstrom, J.C.; Lavigno, B. Searching for Farmland Preservation Markets: Evidence from the Southeastern U.S. Land Use Policy 2009, 26, 121-129. [CrossRef]

42. Nixon, D.V.; Newman, L. The Efficacy and Politics of Farmland Preservation through Land Use Regulation: Changes in Southwest British Columbia's Agricultural Land Reserve. Land Use Policy 2016, 59, 227-240. [CrossRef]

43. Perrin, C.; Nougaredes, B. An Analytical Framework to Consider Social Justice Issues in Farmland Preservation on the Urban Fringe. Insights from Three French Cases. J. Rural Stud. 2020. [CrossRef]

44. Tan, R.; Beckmann, V. Diversity of Practical Quota Systems for Farmland Preservation: A Multicountry Comparison and Analysis. Environ. Plan. C Gov. Policy 2010, 28, 211-224. [CrossRef]

45. He, J.; Liu, Y.; Yu, Y.; Tang, W.; Xiang, W.; Liu, D. A Counterfactual Scenario Simulation Approach for Assessing the Impact of Farmland Preservation Policies on Urban Sprawl and Food Security in a Major Grain-Producing Area of China. Appl. Geogr. 2013, 37, 127-138. [CrossRef]

46. Xu, D.; Yong, Z.; Deng, X.; Zhuang, L.; Qing, C. Rural-Urban Migration and Its Effect on Land Transfer in Rural China. Land 2020, 9, 81. [CrossRef]

47. Li, S.; Li, X.; Sun, L.; Cao, G.; Fischer, G.; Tramberend, S. An Estimation of the Extent of Cropland Abandonment in Mountainous Regions of China. Land Degrad. Dev. 2018, 29, 1327-1342. [CrossRef]

48. Gao, J.; Strijker, D.; Song, G.; Li, S. Drivers Behind Farmers' Willingness to Terminate Arable Land Use Contracts. Tijdschr. Voor Econ. En Soc. Geogr. 2018, 109, 73-86. [CrossRef]

49. Xiao, W.; Zhao, G. Agricultural Land and Rural-Urban Migration in China: A New Pattern. Land Use Policy 2018, 74, 142-150. [CrossRef]

50. Huang, J.; Wang, X.; Zhi, H.; Huang, Z.; Rozelle, S. Subsidies and Distortions in China's Agriculture: Evidence from ProducerLevel Data. Aust. J. Agric. Resour. Econ. 2011, 55, 53-71. [CrossRef]

51. Gale, H.F.; Lohmar, B.; Tuan, F.C. China's New Farm Subsidies. SSRN Electron. J. 2006. [CrossRef]

52. Long, H. Land Use Policy in China: Introduction. Land Use Policy 2014, 40, 1-5. [CrossRef]

53. Liu, X.; Zhao, C.; Song, W. Review of the Evolution of Cultivated Land Protection Policies in the Period Following China's Reform and Liberalization. Land Use Policy 2017, 67, 660-669. [CrossRef]

54. Liu, Z.; Liu, S.; Qi, W.; Jin, H. Urban Sprawl among Chinese Cities of Different Population Sizes. Habitat Int. 2018, 79, 89-98. [CrossRef]

55. Liu, Z.; Liu, S.; Jin, H.; Qi, W. Rural Population Change in China: Spatial Differences, Driving Forces and Policy Implications. J. Rural Stud. 2017, 51, 189-197. [CrossRef]

56. Dimitriadis, P.; Koutsoyiannis, D.; Iliopoulou, T.; Papanicolaou, P. A Global-Scale Investigation of Stochastic Similarities in Marginal Distribution and Dependence Structure of Key Hydrological-Cycle Processes. Hydrology 2021, 8, 59. [CrossRef]

57. Graves, T.; Gramacy, R.; Watkins, N.; Franzke, C. A Brief History of Long Memory: Hurst, Mandelbrot and the Road to ARFIMA, 1951-1980. Entropy 2017, 19, 437. [CrossRef]

58. Koutsoyiannis, D. Climate Change, the Hurst Phenomenon, and Hydrological Statistics. Hydrol. Sci. J. 2003, 48, 3-24. [CrossRef] 